\title{
Kedudukan Hukum Tanah Wakaf di Desa Padang Betuah Kecamatan Pondok Kelapa Ditinjau Dari Undang-Undang Nomor 41 Tahun 2004 Tentang Wakaf
}

\section{The position of Charitable Lands in Padang Betuah Village Pondok Kelapa District viewed from the Law No. 41 year 2004 about the Benefaction}

\section{PIYEN TINORA}

Universitas Muhammadiyah Bengkulu, email: piyen.tinora@gmail.com

\begin{abstract}
ABSTRAK
Di desa Padang Betuah Kecamatan Pondok Kelapa Kabupaten Bengkulu Tengah masih banyak terdapat tanah wakaf yang difungsikan untuk tempat ibadah, pemakaman umum, balai desa dan fasilitas umum lainya, namun kurang diperhatikan oleh nadzhir dalam pengelolaan bangunan, bahkan ada satu bidang tanah wakaf yang nama wakifnya tidak diketahui kerana penyerahan tanah wakaf tersebut terjadi secara lisan dan tanah wakaf tersebut belum bersertifikat atau belum di daftarkan ke pejabat pembuat akta ikrar wakaf untuk di buatkan akta wakaf sesuai dengan peraturan undang-undang nomor 41 tahun 2004, Permasalahan penelitian ini dapat dirumuskan sebagai berikut: 1) berapa banyak tanah wakaf yang ada didesa padang betuah dan dipergunakan untuk apa tanah wakaf tersebut. 2) apakah faktor penyebab tanah wakaf tersebut belum bersertifikat. 3) bagaimana kedudukan hukum tanah wakaf yang belum bersertifikat di tinjau dari undangundang nomor 41 tahun 2004. Metode yang digunakan dalam penulisan ini adalah metode penelitian empiris yaitu data diperolah melalui wawancara mendalam terhadap responden dilapangan. Dari hasil penelitian tersebut didesa padang betuah, terdapat dua bidang tanah wakaf yang sudah dipergunakan untuk pemakaman umum dan satu bidang tanah wakaf masih berupa lahan kosong yang belum di bangun fasilitas umum oleh nadzhir dan pemerintahan desa. Tiga bidang tanah wakaf yang ada didesa padang betuah belum mempunyai sertifikat wakaf sesuai dengan undang-undang tentang wakaf nomor 41 tahun 2004 masalah yang terjadi seperti ini tidak bisa diselesaikan secara hukum karena dalam proses penyerahan wakaf hanya berupa surat penyerahan yang tidak bisa diperkarakan oleh nadzir karena nadzir tidak memiliki sertifikat wakaf yang berkekuatan hukum tetap.
\end{abstract}

\section{Kata Kunci: Tanah Wakaf, Nadzir, sertifikat, sengketa}


Kedudukan Tanah Wakaf di Desa Padang Betuah Kecamatan Pondok Kelapa Ditinjau dari Undang-undang Nomor 41 Tahun 2004 Tentang Wakaf

\section{Abstract}

In Padang Betuah village, Pondok Kelapa District, Central Bengkulu Regency, there are many charitable lands that are functioned for places of worship, public cemetery, village halls and other public facilities, but less attended by nadzhir in the management of buildings, there is even one plot of charitable land with unknown owner because the handover of this charitable land is orally, and it has not been certified or has not been registered to the official of the deed of benefaction pledge to make the deed of benefaction in accordance with the law number 41 year 2004. The problems of this research can be formulated as follows: 1) how many charitable lands that exist in Padang Betuah village are, and for what the charitable lands are used, 2) whether the causal factor of charitable land has not been certified, and 3) how the legal status of charitable land that has not been certified viewed from the law number 41 year 2004. The method used in this research is empirical research method where the data were obtained through in-depth interviews of respondents in the field. From the result of the research, in Padan Betuah village there are two plots of charitable lands that have been used for public cemetery and a plot of charitable land is still a vacant land that has not been built public facilities by nadzhir and village government. Three plots of charitable lands in Padang Betuah village have not had benefaction certificate in accordance with the law on benefaction number 41 year 2004 such problems cannot be resolved legally because in the process of handover of benefaction was only in the form of delivery letter that cannot be exposed by nadzir because nadzir does not have a permanent legal benefaction certificate.

\section{Keywords : Charitable Land, Nadzir, Certificate}

\section{PENDAHULUAN}

Wakaf juga merupakan suatu lembaga keagamaan yang dapat dipergunakan sebagai salah satu sarana guna pengembangan kehidupan keagamaan, khususnya bagi umat yang beragama Islam, dalam rangka mencapai kesejahteraan sepiritual dan material menuju masyarakat adil dan makmur. Wakaf sebagai perbuatan yang mempunyai akibat hukum, adalah perbuatan hukum seseorang atau badan hukum yang memisahkan sebagian dari harta kekayaan baik berupa tanah atau benda lainya dan melembagakannya untuk kepentingan peribadatan dan kepentingan umum lainnya sesuai dengan ajaran agama Islam.

Dengan dilakukan pemisahan harta tersebut dari pemilik asalnya dan dengan dilembagakannya maka benda tersebut tidak hanya terlepas dari pemiliknya akan tetapi telah keluar dari dunia perdagangan sehingga tidak dapat lagi dijadikan obyek jual beli.

Pada waktu yang lalu pengaturan tentang perwakafan di dalam suatu 
perundang-undangan belum ada, sehingga mudah terjadi penyimpangan dari hakikat dan tujuan wakaf itu sendiri, terutama sekali disebabkan terdapatnya beraneka ragam bentuk perwakafan (wakaf keluarga, wakaf umum dan lain-lain) dan tidak ada keharusan untuk didaftarkannya bendabenda yang diwakafkan itu seolah-olah sudah menjadi milik ahli waris atau pengurus (Nazhir). ${ }^{1}$

Mengingat pentingnya persoalan tanah wakaf, sehingga pada tanggal 27 Oktober 2004 pemerintah mengundangkan UndangUndang Nomor 41 Tahun 2004 tentang Wakaf seterusnya disingkat dengan UndangUndang Wakaf. Keberadaan Undang-Undang Wakaf menjadi payung hukum praktik perwakafan, termasuk wakaf tanah di seluruh Indonesia. Di dalam pertimbangan Undang-Undang Wakaf disebutkan, bahwa lembaga wakaf sebagai pranata keagamaan yang memiliki potensi dan manfaat ekonomi perlu dikelola secara efektif dan efisien untuk kepentingan ibadah dan untuk mewujudkan kesajahteraan umum. Wakaf sebagai perbuatan hukum yang telah lama hidup dan dilaksanakan dalam masyarakat, yang pengaturannya belum lengkap serta masih tersebar dalam berbagai peraturan perundang-undangan.

1 Abdurrahman, Masalah Perwakafan Tanah Milik dan Kedudukan Tanah Wakaf di Negara Kita. Alumni, Bandung, 1979, hal 2.
Pernyataan tersebut bermakna bahwa undang-undang wakaf dimaksudkan pula untuk meningkatkan pengaturan wakaf secara lengkap, dengan menghimpun semua produk hukum mengenai wakaf yang selama ini bersebaran dalam berbagai peraturan perundang-undangan, di antaranya yang dimuat dalam peraturan pemerintah mengenai perwakafan tanah milik dan bab wakaf kompilasi hukum Islam. Dengan dibentuknya Undang-Undang Wakaf tersebut maka persoalan-persoalan yang selama ini sering timbul dalam praktik wakaf dapat diatasi.

Perbuatan-perbuatan hukum baik disengaja maupun karena memang tidak mengetahui ketentuan hukum peralihan tanah wakaf, tidak berhenti pada beralinnya tanah wakaf, tetapi mengakibatkan pula terjadinya sengketa tanah horizontal yang menganggu ketertiban masyarakat. Pengamatan peneliti di Desa Padang Betuah Kecamatan Pondok Kelapa Kabupaten Bengkulu Tengah, bahwa pola peralihan tanah wakaf yang sering ditemukan dalam kehidupan masyarakat di antaranya beralihnya fungsi tanah wakaf dari keinginan si wakif oleh nazhir, beralihnya status hukum tanah wakaf karena dipergunakan untuk kepentingan umum, terjadinya peralihan hak tanah wakaf oleh pewaris nazhir dengan akta di bawah tangan, dan pengakuan hak oleh waris wakif 3 . 
Kedudukan Tanah Wakaf di Desa Padang Betuah Kecamatan Pondok Kelapa Ditinjau dari Undang-undang Nomor 41 Tahun 2004 Tentang Wakaf

Selain itu terjadi pula masalah sengketa perwakafan tanah milik, yang disebabkan dalam penyerahan penguasaan tanah wakaf kepada nazhir tidak disertai dengan surat bukti penyerahan. Keadaan ini menyebabkan terjadinya sengketa dari para ahli waris terhadap tanah yang telah diwakafkan oleh pewaris, dan tidak adanya tanggung jawab nazhir dalam mengurus tanah wakaf. Hal itu semua mestinya tidak perlu terjadi apabila semua pihak telah mamahami hukum wakaf. Sengketa juga disebabkan karena belum adanya peraturan perundang-undangan yang mengaturnya secara tuntas dan banyak keaneka ragaman bentuk perwakafan (wakaf umum,wakaf keluarga dan lainlain).

Berdasarkan pada latar belakang diatas maka yang terjadi permasalahan dalam penulisan skripsi adalah sebagai berikut :

1. Berapa banyak tanah wakaf yang ada didesa Padang Betuah dan dipergunakan untuk apa tanah wakaf tersebut?

2. Apakah faktor penyebab tanah wakaf belum disertifikat?

3. Bagaimana kedudukan hukum terhadap tanah tanah wakaf yang belum bersertifikat ditinjau dari undang-undang nomor 41 tahun 2004 ?

\section{METODE PENELITIAN}

Untuk mendapatkan bahan atau data-data yang di perlukan sehubungan dengan masalah yang diteliti penulis membahas beberapa unsur yang harus dipenuhi dalam penelitian sebagai berikut:

Penelitian ini dapat diketegorikan sebagai penelitian yang bersifat penelitian hukum sosiologis atau empiris, sedangkan pengertian hukum sosiologis atau empiris menurut soerjono soekamto adalah, "penelitian hukum yang dilakukan dengan cara meneliti data secara langsung dilapangan (masyarakat) untuk mendapatkan data primer".

\section{Data primer}

Data primer adalah diperoleh dari penelitian lapangan, yaitu dengan cara mengadakan wawancara bebas terpimpin secara langsung terhadap sampel dengan mengajukan daftar pertanyaan yang telah dipersiapkan, daftar pertanyaan itu sebagai alat dalam wawancara di lapangan, dengan tujuan untuk memperoleh / mendapatkan informasi yang berkaitan dengan permasalahan. 
Data Sekunder

Data sekunder adalah di peroleh dengan cara mengadakan penelitian ke perpustakaan (library research) dengan menelaah buku-buku dan peraturan perundang-undangan serta pendapat ahli yang ada hubungannya dengan permasalahan, agar diperoleh teori-teori, asas-asas dan doktrin-doktrin yang berkaitang dengan permasalahan.

Wawancara

Wawancara dilakukan kepada responden antara lain:

a. Bapak Mikratul Aswad,S.HI (Kepala KUA Kecamatan Pondok Kelapa)

b. Bapak Khalidi (Kepala Desa Padang Betuah)

c. Bapak Sukri (Sekretaris Desa Padang Betuah)

d. Bapak Arsil (Kepala dusun Desa Padang Betuah)

e. Sofyan Effendi (Mantan Kepala Desa Padang Betuah)

Dalam melakukan wawancara (memperoleh data) penulis mencatat semua hal yang dibicarakan, hal ini dilakukan untuk memperoleh data yang akurat, juga mempersiapkan daftar pertanyaan sebelum mengadakan wawancara mengenai hal-hal yang akan ditanyakan sesuai dengan data yang dibutuhkan.
Dokumentasi

Data yang didapat dari lapangan, diperiksa kembali guna menentukan data yang terpakai dan selanjutnya akan diseleksi sesuai dengan kedudukan dan klasifikasinya dengan pokok permasalahan, untuk selanjutnya diadakan pengeditan data. Data yang sudah diperiksa, diseleksi dan data yang diklasifikasikan menurut kategori masingmasing, selanjutnya data akan dianalisis dalam bentuk sajian pernyataan baru secara kualitatif untuk menjawab permasalahan.

Data yang telah dikelompokkan dan disusun secara sistematis, selanjutnya dianalisisi secara kualitatif dengan menggunakan pendekatan induktif dan deduktif. Pendekatan induktif yaitu cara berpikir dengan menarik kesimpulan dari data-data yang berrsifat khusus ke data yang bersifat umum. Pendekatan deduktif yaitu cara berpikir dengan menarik kesimpulan dari data-data yang bersifat umum kedata yang bersifat khusus. Berdasarkan analisis tersebut selanjutnya diuraikan secara sistematis sehingga pada akhirnya diperoleh jawaban permasalahan yang disusun dalam bentuk artikel

\section{PEMBAHASAN}


Kedudukan Tanah Wakaf di Desa Padang Betuah Kecamatan Pondok Kelapa Ditinjau dari Undang-undang Nomor 41 Tahun 2004 Tentang Wakaf

\section{Jumlah Tanah Wakaf Di Desa Padang}

Betuah Dan Peruntukannya

Dari hasil wawancara dengan bapak Mikratul Aswad, S.,HI yang menjabat sebagai Kepala Kantor Urusan Agama Kecamatan Pondok Kelapa, didesa Padang Betuah terdapat dua bidang tanah wakaf yang sudah dipergunakan sesuai dengan peruntukan dan satu bidang tanah wakaf masih berupa lahan kosong yang belum di bangun fasilitas umum yang tertera dalam penyerahan akta ikrar wakaf, dua bidang tanah wakaf tersebut di pergunakan untuk fasilitas umum yaitu sebagai berikut:

a. Pemakaman Umum yang tahun penyerahannya dan Wakif yang tidak di ketahui oleh responden karena wakaf penyerahannya terjadi pada zaman dahulu dengan ukuran tanah 20x40 $\mathrm{M}^{2}$.

b. Sebidang tanah kosong diwakafkan pada tahun 2014 dengan ukuran 20x20 $\mathrm{M}^{2}$ dengan Wakif atas nama Herman Syahril.

c. Pemakaman Umum yang tahun penyerahanya tidak diketahui karena penyerahannya hanya berupa lisan dengan ukuran 80x60 $\mathrm{M}^{2}$ dengan Wakif atas nama Goni.
Faktor Penyebab Tanah Wakaf Di Desa Padang Betuah Belum Bersertifikat

Seperti yang diungkapkan Khalidi (Kepala Desa) dan bapak Sukri (Sekretaris Desa) desa Padang Betuah, masyarakat desa Padang Betuah belum memilki pengetahuan tentang UndangUndang perwakafan yang ada di Indonesia.

Hal ini juga di jelaskan oleh bapak Mikratul Aswad,S.,HI "karena belum adanya sosialisasi ulang untuk beberapa tahun kebelakang ini dari pihak Kantor Urusan Agama di Kecamatan Pondok Kelapa".

Adapun faktor penyebab tanah wakaf tersebut belum bersertifikat antara lain:

1. Masyarakat tidak paham proses administrasi tanah wakaf;

2. Minimnya

pengetahuan masyarakat tentang perwakafan;

3. Kantor Urusan Agama belum memberikan sosialisasi ulang tentang perwakafan di Desa Padang Betuah

4. Faktor Penunjang dan Penghambat Nadzir dalam Pengelolaan Tanah Wakaf . 


\begin{abstract}
Nadzir dalam menjalankan fungsinya sebagai pengelola, pemelihara ataupun sebagai pengurus benda - benda ( tanah ) wakaf tentunya dipengaruhi oleh beberapa faktor baik faktor penunjang maupun faktor penghambat.
\end{abstract}

Dari hasil penelitian yang ditemukan penulis dari para nadzir yang dijadikan responden, maka yang menjadi faktor penunjang dalam pengelolaan tanah wakaf di Desa Padang Betuah sebagai berikut :

1. Adanya suatu keyakinan bagi nadzir dengan menjalankan kewajibannya maka nadzir itu mendapat pahala dari Allah.

2. Adanya kerjasama antara nadzir dan masyarakat khususnya pemeliharaan tanah pemakaman.

3. Adanya kesadaran dan rasa tanggung jawab yang tinggi dari nadzir untuk menjalankan tugasnya.

4. Bagi petugas pembersih pemakaman diberi imbalan dan dapat memanfaatkan tanah pemakaman dengan menanami tanaman yang dapat diambil hasilnya.

Kalau dilihat dari keempat faktor penunjang diatas maka tujuan dari ikrar wakaf dapat dimanfaatkan atau digunakan sebagaimana mestinya dan agar tujuan wakaf benar- benar dapat dicapai yaitu untuk beribadah kepada Allah SWT. dengan adanya faktor penunjang ini pengelolaan tanah wakaf yang wajib dilaksanakan oleh nadzir sesuai dengan penggunaan yang biasanya telah telah ditentukan oleh si wakif pada saat dilakukannya ikrar wakaf.

Bila terjadi sengketa tentang wakaf, maka yang pertama kali menyelesaikan atau mengurusnya adalah nadzir yang mengelola tanah wakaf tersebut. Sedangkan faktor penghambat nadzir dalam pengelolaan tanah wakaf adalah :

1. Kemampuan para nadzir yang kurang begitu memadai, terutama dalam hal meningkatkan nilai tambah dari pemanfaatan tanah wakaf.

2. Nadzir dalam menjalankan tugasnya hanya bersifat sampingan jadi sifatnya sukarela.

3. Masih banyak warga masyarakat yang tingkat kesadaran serta rasa tanggung jawabnya kurang terhadap pelaksanaan pengelolaan tanah wakaf. 
Kedudukan Tanah Wakaf di Desa Padang Betuah Kecamatan Pondok Kelapa Ditinjau dari Undang-undang Nomor 41 Tahun 2004 Tentang Wakaf

4. Dana untuk pelaksanaan pengelolaan tanah wakaf kurang memadai, sehingga dalam hal ini dapat pula menjadi faktor penghambat pelaksanaan pengelolaan tanah wakaf.

5. Para nadzir sebelum memangku jabatannya tidak dibekali dengan pengetahuan mengenai Undangundang No. 41 Tahun 2004 dan peraturan serta pelaksanaannya.

Didalam Undang-undang No. 41 Tahun 2004 telah diatur dalam pasal 55 pembinaan nadzir wajib dilakukan seskurang-kurangnya sekali dalam setahun.

Pembinaan ini dilakukan oleh Kantor Urusan Agama Tujuan pembinaan ini adalah untuk meningkatkan etika dan moralitas dalam pengelolaan wakaf serta untuk peningkatan profesional pengelolaan dana wakaf.

Pengawasan terhadap perwakafan dilakukan oleh pemerintah dan masyarakat, baik aktif maupun pasif. Pengawasan aktif yang dimaksud adalah dengan melakukan pemeriksaan langsung terhadap nadzir atas pengelolaan wakaf, sedangkan pengawasan pasif adalah dengan melakukan pengamatan atas berbagai laporan yang disampaikan nadzir berkaitan dengan pegelolaan wakaf.

Hal ini untuk menghindari terjadinya pelanggaran-pelanggaran dan penyalahgunaan wakaf, demi kepentingan masyarakat.

Dari penjelasan dan peraturan yang dijelaskan diatas, maka dapat disimpulkan perwakafan di Indonesia akan berjalan dengan baik apabila masyarakat memahami dan menjalani prosedur perwakafan seperti yang diatur dalam Undang-Undang No 41 Tahun 2004 tentang perwakafan.

Kedudukan Hukum Tanah Wakaf di Desa Padang Betuah yang belum bersertifikat Di Tinjau Dari

\section{Undang-Undang No 41 Tahun 2004}

Pengertian wakaf

Wakaf berasal dari bahasa arab "waqf" yang menurut lughat berarti "menahan". Menurut istilah wakaf berarti menahan harta yang dapat diambil manfaatnya tanpa musnah seketika dan untuk penggunaan yang mubah yang dimaksudkan untuk mendapatkan keridhoan Allah SWT. dalam kitab-kitab fiqih madzhab Maliki lebih banyak digunakan kata Habs, yang artinya sama dengan wakaf 
Bagi mayoritas umat Islam Indonesia, pengertian wakaf yang umum diketahui bahwa, wakaf adalah menahan harta yang dapat dimanfaatkan tanpa lenyap bendanya, dengan cara tidak melakukan tindakan hukum terhadap benda tersebut, disalurkan pada sesuatu yang mubah (tidak haram) yang ada," 2 atau wakaf adalah perbuatan hukum seseorang atau kelompok orang atau badan hukum yang memisahkan sebagian dari benda miliknya guna kepentingan ibadat atau keperluan umum lainnya sesuai dengan ajaran Islam."3

Iman Suhadi menyatakan "Wakaf adalah pemisahan suatu kekayaan atau harta benda seseorang yang dipisahkan dan benda itu "ditarik" dari milik kelompok atau perseorangan, dialihkan penggunaannya ke jalan kebaikan dan diridhoi Allah SWT, sehingga bendabenda itu tidak boleh dihutangkan, dikurangi atau dilenyapkan."4

2al-Ramli.Nihayah al-Muhtaj ila Syarh alMinhaj (Beirut; Dar alfikr. 1984), juz V,h,357,alKhathib al-Syarbaini Muhgai al-Muhtaj (Beirut: Dar al-Fikr,i.th),juz 11,h,376;,http // www mui orid/mui in/article php diakses tgl 24 maret 2015.

3 Komisi Fatwa Majelis Ulama Indonesia,"Keputusan Fatwa Komisi Fatwa Majelis Ulama Indonesia Tentang wakaf Uang" http/www mui or id in/article php Diakses tanggal 24 maret 2015.

4 Imam Suhadi. Hukum Wakaf di Indonesia, Dua Dimensi, Yogyakarta, 1987, hal 13

\section{Benda wakaf}

Benda wakaf adalah "segala benda, baik bergerak atau tidak bergerak, yang memiliki daya tahan dan yang tidak hanya sekali pakai dan bernilai menurut ajaran Islam." 5 Atas dasar pengertian tersebut, bagi mereka hukum wakaf uang (waaf al-nuqud, cash wakaf) adalah tidak sah. Apabila harta benda wakaf yang diwakafkan itu berupa tanah, maka tanah yang bersangkutan haruslah yang bersifat kekal atau tidak dapat habis dalam keadaan normal, karena kegunaan wakaf adalah untuk mengambil hasil atau manfaat benda yang diwakafkan. Dengan demikian apabila benda yang diwakafkan dapat habis dengan begitu saja perbuatan wakaf akan menjadi sia-sia.

Pengertian benda wakaf menurut Undang-Undang Wakaf adalah "harta benda yang memiliki daya tahan lama dan/atau manfaat jangka panjang serta mempunyai nilai ekonomi menurut syariah yang di wakafkan oleh wakif."6

Tentang benda wakaf ini lebih lanjut diatur dalam undang-undang wakaf

${ }^{5}$ Kompilasi Hukum Islam di Indonesia. Buku III, Bab I, Pasal 215 ayat (1) dan (4)

${ }^{6}$ Undang-Undang Nomor 41 Tahun 2004 tentang Wakaf Pasal 1 angka 5 
Kedudukan Tanah Wakaf di Desa Padang Betuah Kecamatan Pondok Kelapa Ditinjau dari Undang-undang Nomor 41 Tahun 2004 Tentang Wakaf

dan peraturan perundangundangan yang berlaku. Pasal 16 yang menentukan :

(1) Harta benda wakaf terdiri dari :

a. benda tidak bergerak dan

b. benda bergerak.

(2) Benda tidak bergerak sebagaimana dimaksud pada ayat (1) huruf a meliputi:

a. hak atas tanah sesuai dengan ketentuan peraturan perundanganundangan yang berlaku baik yang sudah maupun yang belum terdaftar.

b. bangunan atau bagian bangunan yang berdiri di atas tanah sebagimana dimaksud pada huruf a.

c. tanaman dan benda lain yang berkaitan dengan tanah.

d. hak milik atas satuan rumah susun sesuai dengan ketentuan peraturan perundang-undangan yang berlaku.

e. benda tidak bergerak lain sesuai dengan ketentuan syariah

(3) Benda bergerak sebagaimana dimaksud pada ayat (1) huruf b adalah harta benda yang tidak bisa habis karena dikonsumsi, meliputi :
a. uang
b. logam mulia
C. surat berharga

d. kendaraan

e. hak atas kekayaan intelektual

f. hak sewa dan

g. benda bergerak lain sesuai dengan ketentuan syariah dan peraturan perundang-undangan yang berlaku. Benda wakaf dalam konsentrasi penelitian ini dibatasi terhadap benda tidak bergerak berupa tanah.

\section{Hak Penguasaan Atas Tanah Wakaf}

Menurut Boedi Harsono menyatakan bahwa pengertian penguasaan dan menguasai dapat dipakai dalam arti fisik, juga dalam arti yuridis. Juga beraspek perdata dan beraspek publik. ${ }^{7}$ Hak penguasaan tanah di sini merujuk pada hak penguasaan yuridis dan fisik yang beraspek keperdataan.

Penguasaan yuridis dilandasi hak yang dilindungi oleh hukum dan umumnya memberi keweangan kepada pemegang hak untuk menguasai secara fisik tanah yang dihaki. Tetapi ada juga penguasaan yuridis yang biarpun memberi kewenangan untuk menguasai tanah yang dihaki secara fisik, pada kenyataannya penguasaan fisiknya dilakukan pihak lain. Misalnya kalau tanah yang dimiliki dikuasai disewakan kepada pihak lain dan penyewa yang 
menguasainya secara fisik. Atau tanah tersebut dikuasai secara fisik oleh pihak lain tanpa hak. Dalam hal ini pemilik tanah berdasarkan hak penguasaan yuridisnya berhak untuk menuntut diserahkannya kembali tanah yang bersangkutan secara fisik kepadanya. Dalam hukum tanah dikenal juga penguasaan yuridis yang tidak memberi kewenangan untuk menguasai tanah secara fisik. Kreditor pemegang jaminan hak atas tanah mempunyai hak penguasaan yuridis atas tanah yang dijadikan agunan, tetapi penguasaan secara fisik tetap ada pada yang empunya tanah. ${ }^{8}$

Dikaitkan dengan tanah wakaf, maka penguasaan yuridis dan fisik atas tanah wakaf berada pada Nazhir, yaitu pihak yang menerima harta benda wakaf dari wakif untuk dikelola dan dikembangkan sesuai dengan peruntukannya.

Menyangkut masalah tugas nazhir, berdasarkan undang-undang wakaf Pasal 11 sangat jelas ditentukan bahwa dalam pelaksanaan wakaf, nazhir mempunyai tugas:

a. Melakukan

pengadministrasian harta benda wakaf; b. Mengelola dan mengembangkan harta benda wakaf sesuai dengan tujuan, fungsi dan peruntukannya;

c. Mengawasi dan melindungi harta benda wakaf;

d. Melaporkan pelaksanaan tugas kepada Badan Wakaf Indonesia.

\section{Status Hukum Tanah Wakaf}

Status hukum yang peneliti maksudkan di sini berkaitan dengan jenis hak atas tanah. Berdasarkan Pasal 16 ayat (1) Undang-Undang Nomor 5 Tahun 1960 tentang Peraturan Dasar Pokokpokok Agraria ditentukan terdapatnya macam-macam hak atas tanah, yang terdiri dari:
a. hak milik
b. hak guna usaha
c. hak guna bangunan
d. hak pakai
e. hak sewa
f. hak membuka tanah
g. hak memungut hasil hutan
h. hak-hak yang bersifat sementara

Selanjutnya secara khusus mengenai hak-hak atas tanah untuk keperluan suci dan sosial, diatur dalam Pasal 49 Undang-Undang Pokok Agraria yang berbunyi:

(1) Hak milik tanah badan-badan keagamaan dan sosial sepanjang 
Kedudukan Tanah Wakaf di Desa Padang Betuah Kecamatan Pondok Kelapa Ditinjau dari Undang-undang Nomor 41 Tahun 2004 Tentang Wakaf

dipergunakan untuk usaha bidang keagamaan dan sosial diakui dan dilindungi. Badan-badan tersebut dijamin pula akan memperoleh tanah yang cukup untuk bangunan dan usahanya dalam bidang keagamaan dan sosial.

(2) Perwakafan tanah milik dilindungi dan diatur dengan peraturan pemerintah.

Dengan demikian berdasarkan ketentuan di atas, maka status hukum atau jenis hak yang melekat terhadap tanah wakaf bisa berupa hak milik khusus badan keagamaan bisa juga hak pakai untuk keperluan peribadan. ${ }^{13}$

Tanah wakaf yang diberikan dengan status hak milik khusus badan keagamaan, mempunyai sifat yang sama dengan hak milik pada umumnya. Namun perbedaannya, tanah wakaf yang berstatus hak milik itu dikuasai oleh lembaga keagamaan dan dikeluarkan dari obyek perdagangan, karena pemanfaatannya adalah bersifat kekal dan abadi.

Status hak milik atas tanah wakaf atau hak milik atas tanah yang berasal dari wakaf tersebut baru terjadi setelah tanah wakaf didaftarkan menurut peraturan pendaftaran tanah. Dalam Pasal 34 Undang-Undang Nomor 41
Tahun 2004 tentang Wakaf, ditentukan bahwa "Instansi yang berwenang menerbitkan bukti pendaftaran harta benda wakaf." Selanjutnya dalam Pasal 36 diatur pula bahwa:

Dalam hal harta benda wakaf ditukar atau diubah peruntukannya, Nazhir melalui PPAIW mendaftarkan kembali kepada instansi yang berwenang dan Badan Wakaf Indonesia atas harta benda wakaf yang ditukar atau diubah peruntukannya itu sesuai dengan ketentuan yang berlaku dalam tata cara pendaftaran harta benda wakaf.

Menurut Penjelasan Pasal 34 dan Pasal 36 Undang-Undang Nomor 41 Tahun 2004 tentang Wakaf, bahwa instansi yang berwenang di bidang wakaf tanah adalah Badan Pertanahan Nasional. Dengan demikian pendaftaran tanah wakaf yang berstatus hak milik badan keagamaan tersebut tetap menjadi wewenang Kantor Pertanahan Kabupaten/Kota untuk mendaftarkan dan menerbitkan sertifikat tanahnya.

Penelitian ini dapat dikategorikan sebagai penelitian yang bersifat deskriptif. Penelitian deskriptif yaitu penelitian yang ditujukan kepada usaha untuk memperoleh gambaran tentang suatu keadaan pada suatu waktu tertentu (gambaran pada waktu sesaat) 
atau perkembangan tentang sesuatu. ${ }^{9}$ Pendekatan yang juga digunakan adalah pendekatan hukum sosiologis yang bertujuan untuk mengungkap kenyataan dengan mengambil data berdasarkan fakta yang terjadi dalam praktik perwakafan tanah di Desa Padang Betuah.

Mengenai kedudukan tanah wakaf terdapat perbedaan pendapat dikalangan Islam yaitu sebagai berikut :

Hanafiah berpendapat bahwa tanah wakaf tetap menjadi milik orang yang mewakafkan ( wakif ), hal ini didasarkan kepada pendapatnya pada riwayat Ibnu Abbas R.A yang berbunyi :

" Diriwayatkan dari Ibnu Abbas, ia berkata : setelah ayat tentang fara'idl dalam surat An Nisa' turun, Rasulullah SAW bersabda : Tiada wakaf setelah turunnya surah An Nisa"' ( HR.AI Baihaqi ) .

Dari hadist diatas dapatlah kita ketahui bahwa mereka menetapkan wakaf tetap hak milik wakif, Sehingga pada suatu saat harta wakaf dapat kembali kepada si wakif atau di wariskan apabila ia meninggal dunia.

J. Supranto, Metode Penelitian Hukum dan Statistik, PT. Bhineka Cipta, Jakarta, 2003, Hal 4.
Pendapat tersebut diatas bertentangan dengan hadist riwayat Ibnu Umar yang mengatakan bahwa harta wakaf itu benda, pokoknya tidak boleh dijual, dihibahkan dan diwariskan. Hal ini berlandaskan kepada sabda Rasulullah SAW yang berbunyi :

" Jika kamu mau, tahan asal bendanya dan kamu sedekah hasilnya "

Pendapatnya didukung oleh imam Syafe'i dan Hambali bahwa harta wakaf itu putus atau keluar dari hak milik si wakif dan menjadi milik Allah atau milik umum. Si wakif tidak dapat menarik kembali dan membelanjakannya yang dapat mengakibatkan perpindahan hak milik, dan juga ia tidak dapat mengikrarkan bahwa harta wakaf itu menjadi hak milik orang lain juga tidak dapat dijual, digadaikan, dihibahkan, serta di wariskan.

Sebagaimana yang diketahui bahwa salah satu akibat atau dampak dari sengketa didesa Padang Betuah, bahwa dalam perwakafan yang tidak dilengkapi sertifikat akta ikrar wakaf dapat terjadi perebutan hak atas tanah antara ahli waris dan nadzir.

Dari informasi yang di dapat dari Bapak Mikratul Aswad,S.HI (kepala KUA Pondok Kelapa) ada tiga bidang tanah wakaf yang ada didesa Padang Betuah belum mempunyai sertifikat wakaf sesuai 
Kedudukan Tanah Wakaf di Desa Padang Betuah Kecamatan Pondok Kelapa Ditinjau dari Undang-undang Nomor 41 Tahun 2004 Tentang Wakaf

dengan undang-undang tentang wakaf Nomor 41 Tahun 2004 namun hanya berupa penyerahan dalam bentuk surat penyerahan akta ikrar wakaf yang tidak mempunyai kedudukan hukum yang tetap sehingga dapat menimbulkan masalah di kemudian hari.

Praktek wakaf yang terjadi dalam kehidupan masyarakat belum sepenuhnya berjalan tertib dan efisien, sehingga dalam berbagai kasus harta wakaf tidak terpelihara sebagaimana mestinya, terlantar atau beralih ke tangan pihak ketiga dengan cara melawan hukum. Keadaan disebabkan tidak hanya kelalaian atau ketidakmampuan Nazhir dalam mengelola dan mengembangan benda wakaf melainkan juga sikap masyarakat yang kurang peduli atau belum memahami status benda wakaf yang seharusnya dilindungi demi untuk kesejahteraan umum sesuai dengan tujuan, fungsi dan peruntukan wakaf.

Sengketa bisa terjadi apabila tanah wakaf tidak memiliki sertifikat tanah wakaf seperti yang terjadi di desa Padang Betuah. Tanah wakaf tersebut hanya memiliki surat pernyataan wakaf dari wakif dan ditanda tangani oleh Kepala Desa, Nadzir serta KUA. Surat tersebut tidak dapat dijadikan sebagai kekuatan hukum seperti yang diatur dalam UndangUndang No. 41 Tahun 2004.

Sebagai contoh sengketa yang diungkapkan oleh Sofyan Efendi ( mantan Kepala Desa ), sengketa yang terjadi di Desa Padang Betuah yaitu ada seorang anak wakif yang bernama Muhtadin, ia tidak mengetahui bahwa orang tuanya telah mewakafkan sebidang tanah milik dan proses wakaf tersebut tidak disertai Akta Ikrar Wakaf. dan beberapa tahun kemudian wakif tersebut meninggal dunia, dan pada suatu hari Muhtadin tersebut ingin menjual atau mendirikan bangunan atau fasilitas lain di lokasi tanah tersebut diwakafkan. Sedangkan tanah wakaf tersebut tidak memiliki Akta Ikrar Wakaf, maka secara hukum tanah tersebut masih milik Mutadin yang merupakan ahli waris dari tanah tersebut.Berdasarkan hasil musyawarah desa Kepala Desa padang betuah kemudian memberi uang kepada Muhtadin sebagai pengganti tanah, uang tersebut berasal dari kas desa yang digunakan untuk kepentingan masyarat desa Padang Betuah. Tanah tersebut oleh Kepala Desa didirikan balai desa sebagai tempat pelayanan masyarakat desa Padang Betuah.

Dari informasi yang didapat dari Bapak Sukri (Sekretaris Desa) dan hasil observasi penulis ke pemakaman umum 
desa Padang Betuah terdapat pematokan atau pemagaran tanah pemakaman dengan ukuran $5 \times 10 \mathrm{~m}^{2}$ didesa Padang Betuah atas nama wakif Goni, tanah tersebut di pagar atau di patok oleh Mukminin (alm) yang sekarang di kuasai sebagai ahli waris anaknya yang bernama Mun. Dari pihak nadzhir yaitu pemerintah desa padang betuah, tidak bisa bertindak apaa-apa, dikarenakan tidak adanya sertifikat atas tanah wakaf tersebut.

Dari sengketa yang terjadi didalam lingkungan masyarakat maka pada tahun 2004 sudah ditetapkan undang -undang wakaf yang mengatur tentang tata cara wakaf dan ketentuan bahwa setiap harta wakaf harus dilaporkan dan mempunyai sertifikat, akan tetapi tidak adanya rasa kepedulian Nazhir, Wakif dan masyarakat untuk mengurus dan memperbaharui data -data harta wakaf tersebut untuk di laporkan kepada pihak Kantor Urusan Agama maupun pemerintah untuk disahkan. Bahkan masih banyak masyarakat yang memiliki pola pikir bahwa tanah wakaf tersebut tidak akan di campur tangankan dan dipindah alihkan oleh orang ketiga, padahal sudah ada contoh kasus yang terjadi dalam masyarakat, tanah wakaf di ambil alih oleh pihak yang melanggar hukum.. Jadi tanah wakaf yang tidak memiliki sertifikat wakaf dapat menimbulkan berbagai macam masalah dikemudian hari apabila masyarakat tidak mengurus surat Akta Ikrar Wakaf dari Kantor Urusan Agama.

Hal ini diatur dalam Undang- Undang No 41 Tahun 2004 pasal 69 ayat 2 yang berbunyi : " wakaf wajib didaftarkan dan diumumkan paling lama 5 (lima) tahun sejak Undang-undang ini diundangkan":

Dengan memperhatikan pasal tersebut, maka dalam hal perwakafan mengutamakan kepentingan masyarakat umum seperti yang diatur dalam UndangUndang No 41 Tahun 2004 pasal 1 ayat 1 yang berbunyi :

" wakaf adalah perbuatan hukum wakif untuk memisahkan dan/atau menyerahkan sebagian harta benda miliknya untuk dimanfaatkan selamanya untuk jangka waktu tertentu sesuai dengan kepentingannya guna keperluan ibadah dan/atau kesejahteraan umum menurut syariah Islam.

\section{PENUTUP}

\section{Kesimpulan}

Dari uraian - uraian diatas, dapat ditarik beberapa kesimpulan yang sesuai dengan permasalahan yang terjadi didesa Padang Betuah sebagai berikut

1. Terdapat dua bidang tanah wakaf yang sudah dipergunakan sesuai dengan peruntukannya dan satu bidang tanah wakaf yang masih 
Kedudukan Tanah Wakaf di Desa Padang Betuah Kecamatan Pondok Kelapa Ditinjau dari Undang-undang Nomor 41 Tahun 2004 Tentang Wakaf

berupa lahan kosong yang belum dibangun fasilitas umum yang tertera dalam penyerahan akta ikrar wakaf, dua bidang tanah wakaf tersebut dipergunakan untuk pemakaman umum.

2. Faktor penyebab belum bersertifikatnya tanah wakaf disebabkan tidak pahamnya masyarakat dengan tata cara pewakafan, minimnya pengetahuan masyarakat tantang undang-undang perwakafan, rasa tidak peduli masyarakat kepada tanah wakaf dan belum adanya sosialisasi ulang dari pihak KUA maupun pemerintah terhadap Perangkat desa yang baru tentang wakaf guna di lakukan untuk menunjang pembangunan dan pemeliharaan tanah wakaf.

3. Ada tiga bidang tanah wakaf yang ada didesa padang Betuah belum mempunyai sertifikat wakaf sesuai dengan undang-undang nomor 41 tahun 2004, namun hanya berupa penyerahan dalam bentuk surat penyerahan akta ikrar wakaf yang tidak mempunyai kedudukan hukum yang tetap sehingga dapat menimbulkan masalah dikemudian hari. Kedudukan hukum tanah wakaf di tinjau dari undangundang tentang wakaf Nomor 41 Tahun 2004 yang ada didesa Padang betuah tidak memiliki kedudukan hukum yang tetap karena tidak mempunyai sertifikat yang di atur sesuai dengan undang-undang maka masyarakat memerlukan sosialisasi ulang dari Pemerintah atau KUA tentang undang-undang perwakafan supaya tanah wakaf di Desa Padang Betuah mempunyai sertifikat dan mempunyai kedudukan hukum yang tetap sehingga para nadzir dapat bekerja sesuai dengan tugasnya yang diatur dalam UndangUndang No. 41 Tahun 2004.

\section{Saran}

Sehubungan dengan beberapa persoalan yang dihadapi yaitu yang dapat menghambat dalam pelaksanaan fungsi nadzir dalam pengelolaan tanah wakaf di Desa Padang Betuah seperti yang telah dikemukakan diatas maka dapatlah dikemukakan beberapa saran dengan harapan dapat bermanfaat bagi Wakif, Nazhir dan Kantor Urusan Agama maupun masyarakat yang ada di Desa Padang Betuah khususnya dan warga masyarakat 


\section{P-ISSN : 2599-1892}

Vol. 1, No. 1, Januari 2018

umumnya dalam rangka menunjang pelaksanaan pengelolaan wakaf, saran saran tersebut adalah :

1. Agar semua Wakif dan Nadzir dapat memperbaharui data-data mengenai tahun penyerahan wakaf, ukuran tanah tanah wakaf dan mengurus dan memelihara tanah wakaf dengan baik sehingga tujuan wakaf dari wakif tersebut sesuai dengan ikrar wakaf.

2. Agar Pemerintah dan KUA dapat melakukan sosialisasi ulang terhadap pemerintahan desa yang baru dan masyarakat sehingga tidak ada lagi tanah wakaf yang tidak memiliki sertifikat wakaf dan masyarakatpun lebih paham cara, tujuan dan pemanfaatan tanah wakaf.

3. Hendaknya Nazhir dan wakif bisa segera membuat sertifikat tanah wakaf tersebut sehingga tanah wakaf tersebut tidak menimbulkan berbagai kasus, harta wakaf tidak bersertifikat sebagaimana mestinya atau beralih ke tangan pihak ketiga dengan cara melawan hukum. Keadaan tersebut tidak hanya kalalaian Wakif, Nazhir, KUA maupun Pemerintah dalam mengelola dan mengembangkan benda wakaf melainkan juga sikaf masyarakat yang kurang peduli atau belum memahami fungsi, tujuan dan peruntukan wakaf.

\section{DAFTAR PUSTAKA}

Abdurrahman, 1979, Masalah Perwakafan Tanah Milik dan Kedudukan Tanah Wakaf di Negara Kita, Alumni, Bandung

Ahmad Azhar Basyir, 1987, "Hukum Islam Tentang Wakaf, ijarah dan syirkah", al-Ma'arif, Bandung

Ahmad Faishal Haq, dan Ahmad Saiful Anam, 1994, Hukum Wakaf dan Perwakafan di Indonesia, Pasuruan, PT. GBI, Cetakan ke-4

Amir Hamzah, 1992, Kompilasi Hukum Islam Buku II Hukum Perwakafan, Penerbit Universitas Brawijaya, Malang

Boedi Harsono, 1999, Hukum Agraria Indonesia Sejarah Pembentukan UUPA, Isi dan Pelaksanaannya, Djambatan, Jakarta.

Departemen Agama RI Direktorat Jenderal Bimbingan Masyarakat Islam, 2006, Peraturan Perundangan Perwakafan, Jakarta

Direktorat Peningkatan Zakat dan Wakaf Ditjen BIPH, 2006, Proses Lahirnya Undang-Undang Nomor 41 Tahun 2004 tentang Wakaf, Jakarta, Depag RI

Direktorat Pemberdayaan Wakaf Direktorat Jenderal Bimbingan Masyarakat Islam, 2006, Panduan Pemberdayaan Tanah Wakaf 
Kedudukan Tanah Wakaf di Desa Padang Betuah Kecamatan Pondok Kelapa Ditinjau dari Undang-undang Nomor 41 Tahun 2004 Tentang Wakaf

Produktif Strategis di Indonesia, Jakarta, Departemen Agama RI

Imam Suhadi, 1987, Hukum Wakaf di Indonesia, Dua Dimensi, Yogyakarta

\begin{tabular}{l} 
2002, Wakaf Untuk \\
\hline Kesejahteraan Umat, Yogyakarta, \\
PT. Dana Bhakti Prima Yasa
\end{tabular}

J. Supranto, 2003, Metode Penelitian Hukum dan Statistik, Jakarta, Bhineka Cipta.

Ronny Hanitijo. S., 1994, Metodologi Penelitian Hukum dan Juru Metri, Jakarta, Ghalia Indonesia

http/www.mui or id/article php, Keputusan Fatwa Komisi Majelis Ulama Indoensia tentang Wakaf Uang, diakses, tanggal 24 Maret 2015.

Undang-Undang Nomor 41 tahun 2004 tentang wakaf 